\title{
PENERAPAN MODEL SKRIP KOOPETARIF DALAM PEMBELAJARAN BAHASA INDONESIA
}

\author{
Sarjima \\ SMPN 2 Jamblang Cirebon, Indonesia \\ sarjima789@gmail.com
}

\begin{abstract}
The problem faced in this study is the lack of students 'ability to understand Indonesian language learning materials, such as the lack of students' ability to express thoughts, feelings, and information in the form of reviews and essays. This study aims to improve students' ability to understand Indonesian language learning material about "Reviewing Science Books" with the Cooperative Script Model. This research is a Classroom Action Research (CAR) which was carried out in two cycles with the research subjects as students of IXD grade at SMPN 2 Jamblang, Cirebon Regency. The results showed an increase in student activity and learning outcomes in learning Indonesian after applying the cooperative script model. Thus it can be concluded that the Cooperative Script Model can Improve Students' Understanding in Indonesian Language learning in the Review of Science Books material.
\end{abstract}

Keywords: learning outcomes, Indonesian Cooperative Script Model

\begin{abstract}
ABSTRAK
Masalah yang dihadapi dalam penelitian ini adalah masih kurangnya kemampuan siswa dalam memahami materi pembelajaran Bahasa Indonesia, seperti kurangnya kemampuan siswa dalam mengungkapkan pikiran, perasaan, dan informasi dalam bentuk resensi dan karangan. Penelitian ini bertujuan untuk meningkatkan kemampuan siswa dalam memahami materi pembelajaran Bahasa Indonesia tentang "Meresensi Buku Ilmu Pengetahuan" dengan Model Skrip Kooperatif. Penelitian ini merupakan Penelitian Tindakan Kelas (PTK) yang dilaksanakan dua siklus dengan subyek penelitian adalah siswa kelas IXD SMPN 2 Jamblang Kabupaten Cirebon. Hasil penelitian menunjukkan terjadi peningkatan aktivitas dan hasil belajar siswa dalam pembelajaran bahasa Indonesia setelah menerapkan model skrip kooperatif. Dengan demikian dapat disimpulkan bahwa Model Skrip Kooperatif dapat Meningkatkan Pemahaman siswa dalam pembelajaran Bahasa Indonesia pada materi Meresensi Buku Ilmu Pengetahuan.
\end{abstract}

Kata Kunci : Hasil belajar, Bahasa Indonesia, kooperatif skrip

\begin{tabular}{l|l|l} 
Submitted Mar 29, 2020 & Revised May 14, 2020 & Accepted May 18, 2020
\end{tabular}

\section{Pendahuluan}

Belajar merupakan suatu proses yang ditandai dengan adanya perubahan pada diri seseorang. Perubahan sebagai hasil proses belajar dapat ditunjukkan dalam berbagai bentuk seperti berubah pengetahuan, pemahaman, sikap dan tingkah laku, keterampilan, kecakapan, kemampuan, daya penerimaan dan lain-lain (Sudjana, 2012). Agar proses pembelajaran berjalan efektif, seorang guru harus kompeten untuk membelajarkan siswa dan membuat siswa lebih aktif serta termotivasi dalam proses pembelajaran. Hasil belajar yang optimal merupakan tujuan utama yang ingin dicapai dalam proses pembelajaran. Untuk mengoptimalkan hasil belajar siswa diperlukan model pembelajaran yang sesuai dengan materi ajar (Zain, 2006). Ilmu bahasa sebagai bagian dari sastra berkaitan dengan cara mencari tahu dan memahami secara sistematis. Seseorang yang mempelajari ilmu bahasa tidak hanya membutuhkan keterampilan saja, tetapi juga diperlukan proses berfikir untuk memahami, 
menemukan, dan mengembangkan konsep dalam kehidupan sehari-hari. Materi dalam mata pelajaran bahasa indonesia sifatnya tidak hanya menghafal, tetapi dibutuhkan juga pemahaman, analisis dan kemampuan siswa untuk mengaitkan pembelajaran pada kehidupan sehari-hari.

Pada pengamatan awal di SMPN 2 Jamblang Kabupaten Cirebon menunjukkan kenyataan bahwa proses KBM berjalan secara teoritis dan tidak terkait dengan lingkungan nyata tempat siswa berada. Padahal kondisi lingkungan sekolah sangat memungkinkan untuk diadakannya kegiatan pembelajaran, yang dalam pelaksanaannya tidak harus di dalam laboratorium. Sehingga siswa hanya dapat membayangkan obyek yang sedang dipelajarinya secara abstrak. Pada gilirannya minat dan motivasi serta keaktifan siswa menurun. Hal ini dapat dilihat dari hasil belajar siswa yang belum mencapai ketuntasan belajar baik secara individu maupun secara klasikal. Hasil pengamatan awal ketuntasan belajar siswa hanya mencapai $60 \%$. Ketidaktuntasan hasil belajar siswa dipengaruhi oleh banyak faktor, seperti fasilitas sekolah yang kurang memadai, pemilihan metode pembelajaran yang kurang tepat, media pembelajaran kurang menarik dan tingkat keaktifan siswa yang rendah.

Untuk mengatasi masalah tersebut, diperlukan adanya sebuah strategi pembelajaran yang lebih memberdayakan siswa, yaitu suatu pendekatan pembelajaran yang mampu meningkatkan minat dan motivasi siswa. Penerapan model pembelajaran yang tepat diharapkan dapat mengatasi rendahnya hasil belajar siswa dengan menciptakan suasana yang menyebabkan siswa termotivasi dan aktif dalam belajar. Jika siswa aktif, maka diharapkan hasil belajar siswa dapat meningkat (Aryati, 2017). Pendekatan pembelajaran ini salah satunya menekankan kepada bagaimana belajar di sekolah, yaitu Model Skrip Kooperatif. Model pembelajaran kooperatif merupakan salah satu model pembelajaran yang sangat popular untuk diterapkan dalam berbagai bidang studi (Kusumawati \& Sukidi, 2014). Model pembelajaran Kooperatif didefinisikan sebagai penggunaan pembelajaran kelompok kecil (Adi, Phang, \& Yusof, 2012) sehingga siswa bekerja sama untuk memaksimalkan diri mereka sendiri, berpartisipasi langsung (Sriarunrasmee, Suwannatthachote, \& Dachakupt, 2015) dan terlibat secara aktif dalam pembelajaran (Johnson \& Johnson, 1999) serta belajar bersama satu sama lain untuk mencapai tujuan pembelajaran (Oxford, 1997)(Buchs, Gilles, Dutrévis, \& Butera, 2011) memecahkan masalah, menyelesaikan tugas atau membuat produk (Laal \& Ghodsi, 2012)(Laal, Khattami-Kermanshahi, \& Laal, 2014).

Model pembelajaran kooperatif terdiri dari berbagai tipe, salah satunya yaitu model pembelajaran Cooperative Script. Model pembelajaran ini dapat diterapkan pada pembelajaran yang bersifat kognitif, karena setiap peserta didik nantinya diberikan materi ajar secara lengkap, dibagi berpasang-pasangan dan masing-masing dari mereka bergantian secara lisan mengintisarikan materi yang telah diberikan, dan pasangan lainnya mengoreksi apakah benar pernyataan yang diungkapkan oleh temannya tersebut atau tidak (Meilani \& Sutarni, 2016). Model pembelajaran cooperative script mempunyai peran strategis dalam upaya mendongkrak hasil belajar siswa. Dalam penerapannya guru menyesuaikan dengan kondisi kebutuhan siswa, sehingga guru diharapkan mampu menyampaikan materi dengan tepat tanpa mengakibatkan siswa mengalami kebosanan (Salamiah, 2018).

Dengan konsep belajar tersebut, penulis merasa yakin bahwa pemahaman pada materi "Meresensi Buku Ilmu Pengetahuan" akan meningkat secara signifikan. Karena itu, penulis akan melakukan penelitian tindakan kelas di kelas IXD SMPN 2 Jamblang Kabupaten Cirebon dengan menerapkan Model Skrip Kooperatif dalam proses pembelajarannya. 


\section{Metode Penelitian}

Metode yang digunakan dalam penelitian ini adalah penelitian tindakan kelas. Penelitian Tindakan Kelas merupakan penelitian tindakan dalam bidang pendidikan yang dilaksananakan dalam kawasan kelas dengan tujuan untuk memperbaiki dan atau meningkatkan kualitas pembelajaran (Kasbolah, 2001). Penelitian tindakan kelas merupakan suatu pencermatan terhadap kegiatan yang sengaja dimunculkan, dan terjadi dalam sebuah kelas (Arikunto, 2006). Penelitian tindakan kelas dilakukan oleh seorang guru di dalam kelasnya sendiri melalui refleksi diri, dengan tujuan untuk memperbaiki kinerjanya sebagai guru, sehingga hasil belajar siswa menjadi meningkat (Wardani, 2007).

Penelitian ini dilaksanakan di SMPN 2 Jamblang Kabupaten Cirebon dengan Subjek penelitian adalah siswa kelas IXD SMPN 2 Jamblang tahun ajaran 2019/2020 sebanyak 35 siswa. Dalam pengambilan subyek penelitian ini didasarkan pada kondisi kelas IXD secara keseluruhan.

\section{Hasil dan Pembahasan}

Kegiatan pembelajaran dalam penelitian tindakan kelas dilaksanakan 2 siklus, masingmasing siklus terdiri dari studi pendahuluan, perencanaan, tindakan, observer dan refleksi kegiatan yang dilaksanakan.

Pada siklus pertama penulis melakukan: a) identifikasi permasalahan menyangkut bahan pelajaran yang digunakan, strategi pembelajaran yang biasa digunakan. Pada siklus ini menggunakan pendekatan konvensional, b). menyajikan materi pembelajaran "Meresensi Buku Ilmu Pengetahuan", c). melakukan pengamatan dengan menggunakan observasi dan pemotretan, d). mengukur dampak pendekatan konvensional digunakan daftar aktivitas siswa.

Kegiatan pembelajaran pada studi pendahuluan umumnya menggunakan pembelajaran konvensional, yang meliputi ceramah, tanya jawab dan memberikan tugas. Guru menjelaskan materi yang dapat memotivasi belajar siswa kelas IXD. Adapun materi pembelajaran Bahasa Inadonesia pada siklus I (pertama) dapat dikemukakan sebagai berikut.

1) Materi Pembelajaran Bahasa Indonesia adalah "Meresensi Buku Ilmu Pengetahuan".

2) Standar Kompetensi pembelajaran bahasa Indonesia pada materi tersebut adalah: mengungkapkan pikiran, perasaan, dan informasi dalam bentuk resensi dan karangan.

3) Kompetensi dasar pembelajaran bahasa Indonesia pada materi tersebut adalah: merersensi buku pengetahuan.

4) Mengukur kompetensi dengan melakukan evaluasi.

Pada tahap perencanaan, penulis mengadakan kolaborasi dengan guru lain dalam menyusun rencana penelitian, yang meliputi: 1) tujuan pembelajaran, 2) kompetensi dan materi pembelajaran, 3) strategi pembelajaran berupa Model pembelajaran, serta sumber belajar dan 4) evaluasi hasil belajar.

Pada pelaksanaan tindakan, kegiatan pembelajaran dimulai dengan guru membagi siswa menjadi 6 kelompok. Tiap kelompok diberikan acuan materi pembelajaran dan diminta untuk menghubungkan materi lalu dengan materi sekarang. Pada proses pembelajaran dengan menggunakan Model Skrip Kooperatif, guru meminta siswa untuk berpasangan. Guru memberikan arahan bahwa siswa agar bertanggung jawab atas segala sesuatu di dalam kelompoknya, seperti milik mereka sendiri. Selanjutnya siswa mengerjakan tugas yang diberikan guru pada lembar kerja. Hasil pekerjaan siswa dipresentasikan di depan kelas. 
Adapun siswa dari kelompok lain menyimak/ mengoreksi/ menunjukkan ide-ide pokok yang kurang lengkap serta membantu, mengingat/ menghapal ide-ide pokok dengan menghubungkan materi sebelumnya atau dengan materi lainnya. Di akhir pembelajaran guru bersama siswa memberi kesimpulan hasil kerja kelompok, dan dilakukan evaluasi.

Kegiatan pembelajaran di kelas diamati oleh seorang observer dengan mengamati kegiatan awal pembelajaran, ketika guru membuka pelajaran seperti apersepsi terhadap materi yang akan dibahas dan memberikan motivasi kepada siswa. Pada siklus pertama observer kinerja guru dalam kegiatan pembelajaran, seperti pada kegiatan pendahuluan, kegiatan inti, kegiatan akhir dari pembelajaran dan suasana kelas selama proses pembelajaran. Dari hasil observasi diperoleh hasil bahwa kegiatan pembelajaran mencapai keberhasilan sebesar 46\% dengan kategori cukup baik. Dari hasil ini dapat disimpulkan bahwa kemampuan guru dalam mengajar, sikap guru dalam pelajaran, penguasaan materi, proses pembelajaran, pemakaian media, kemampuan menutup pelajaran dinilai cukup oleh observer.

Dari hasil pengamatan aktivitas siswa diperoleh keberhasilan sebesar 68\% dengan kategori cukup baik. Dengan demikian dapat disimpulkan bahwa perhatian siswa dalam kegiatan belajar mengajar, keberanian, jawaban siswa, kesungguhan dalam mengikuti pelajaran, keseriusan mengerjakan soal ringan dan berat dinilai observer adalah cukup.

Penelitian pada siklus II dilakukan dengan melakukan indentifikasi permasalahan menyangkut bahan pelajaran yang digunakan, setrategi pembelajaran yang biasa digunakan, menyajikan materi pembelajaran, serta melakukan pengamatan dengan menggunakan observasi dan pemotretan sebagai evaluasi pembelajaran. Dalam studi pendahuluan, Guru menjelaskan materi lanjutan "Meresensi Buku Ilmu Pengetahuan" dan menanggapi isi laporan di kelas IXD SMP

Pada tahap perencanaan, penulis mengadakan kolaborasi dengan guru lain dalam menyusun rencana penelitian, yang meliputi: 1) tujuan pembelajaran, 2) kompetensi dan materi pembelajaran, 3) strategi pembelajaran berupa metode dan media yang digunakan serta sumber belajar, dan 4) evaluasi hasil belajar.

Pada pelaksanaan tindakan, kegiatan pembelajaran dimulai dengan guru membagi kelompok tetap menjadi 6 kelompok.. Guru membagi wacana lanjutan untuk siklus II. pada tiap siswa untuk dibaca dan membuat ringkasan dalam masing-masing kelompok. Siswa dibagi tugas dan harus memiliki tanggung jawab yang sama di antara anggota kelompoknya. Hasil kerja kelompok dipresentasikan di depan kelas, dengan membacakan ringkasannya selengkap mungkin, dengan memasukkan ide-ide pokok dalam ringkasannya. Di akhir pembelajaran, guru bersama siswa memberi kesimpulan hasil kerja kelompok dan melakukan evaluasi.

Hasil observasi pada siklus kedua diperoleh temuan bahwa timbulnya perhatian siswa terhadap mata pelajaran Bahasa Indonesia dengan aktivitas mereka merespon proses pembelajaran "Meresensi Buku Ilmu Pengetahuan", timbulnya keberanian siswa untuk tampil membaca dan memahami isi bacaan serta menjawab soal, kesanggupan dan kemampuan siswa mengajukan pertanyaan, kemampuan dan kejelihan siswa untuk menghindari kekeliruan dalam menjawab soal, perhatian siswa menyelesaikan soal-soal yang ditugaskan,

Dari hasil observasi aktivitas siswa diperoleh keberhasilan mencapai 88\% dengan kategori baik sekali. Dengan demikian dapat disimpulkan bahwa perhatian siswa dalam KBM, keberanian, jawaban siswa, kesungguhan dalam mengikuti pelajaran, keseriusan mengerjakan 
soal ringan dan berat dinilai observer baik (B) kesanggupan, jawaban dan keberanian siswa dinilai sangat baik (B).

Dari hasil observasi penerapan model skrip kooperatif diperoleh hasil bahwa kegiatan pembelajaran mencapai keberhasilan sebesar 89\% dengan kategori baik sekali. Jadi, dapat disimpulkan bahwa kemampuan guru dalam pelajaran, sikap guru dalam pelajaran, penguasaan materi, proses pembelajaran, pemakaian media, kemampuan menutup pelajaran dinilai baik oleh observer.

Kegiatan pembelajaran Bahasa Indonesia pada materi "Meresensi Buku Ilmu Pengetahuan" melalui penelitian tindakan kelas di kelas IXD SMPN 2 Jamblang pada semester genap tahun 2019/2017 dengan menerapkan Model Skrip Kooperatif diperoleh nilai siswa pada siklus I dan II baik secara individu maupun secara kelompok yaitu:

Tabel 1

Nilai Evaluasi Belajar Siswa pada tiap Siklus

\begin{tabular}{|c|c|c|c|c|c|}
\hline \multirow[b]{2}{*}{ No } & \multirow[b]{2}{*}{ Nama } & \multirow[b]{2}{*}{$\mathrm{L} / \mathrm{P}$} & \multicolumn{3}{|c|}{ Nilai } \\
\hline & & & Pra Test & Siklus 1 & Siklus 2 \\
\hline 1 & Adi Juliardi & $\mathrm{L}$ & 40 & 60 & 75 \\
\hline 2 & Agus Supriatna & $\mathrm{L}$ & 40 & 60 & 75 \\
\hline 3 & Ahmad & $\mathrm{L}$ & 50 & 60 & 80 \\
\hline 4 & Aldi Yusup Rpiyono & $\mathrm{L}$ & 60 & 70 & 80 \\
\hline 5 & Anita Viktoria & $\mathrm{P}$ & 40 & 60 & 75 \\
\hline 6 & Arif Hidayat & $\mathrm{L}$ & 50 & 70 & 80 \\
\hline 7 & Ariyanto & $\mathrm{L}$ & 40 & 60 & 80 \\
\hline 8 & Arya Mega Saputra & $\mathrm{L}$ & 60 & 70 & 80 \\
\hline 9 & Cahyati & $\mathrm{P}$ & 60 & 70 & 80 \\
\hline 10 & Dea Imas Maesaroh & $\mathrm{P}$ & 50 & 70 & 80 \\
\hline 11 & Dede Parid Maulana & $\mathrm{L}$ & 60 & 80 & 80 \\
\hline 12 & Dewi Khoirunnisa & $\mathrm{P}$ & 50 & 60 & 80 \\
\hline 13 & Eliza Tuzahroh & $\mathrm{P}$ & 60 & 80 & 80 \\
\hline 14 & Fajrin & $\mathrm{L}$ & 40 & 70 & 80 \\
\hline 15 & Gunawan & $\mathrm{L}$ & 50 & 70 & 90 \\
\hline 16 & Habiburrohman R.Z. & $\mathrm{L}$ & 60 & 70 & 80 \\
\hline 17 & Hariyanto & $\mathrm{L}$ & 60 & 70 & 80 \\
\hline 18 & Hilliyatul Aulina & $\mathrm{P}$ & 40 & 60 & 75 \\
\hline 19 & Ita Rositawati & $\mathrm{P}$ & 70 & 80 & 90 \\
\hline 20 & Ivan Efendi & $\mathrm{L}$ & 50 & 60 & 75 \\
\hline 21 & Junedi & $\mathrm{L}$ & 60 & 70 & 80 \\
\hline 22 & Lili Salma & $\mathrm{P}$ & 70 & 80 & 90 \\
\hline 23 & Linawati & $\mathrm{P}$ & 70 & 80 & 90 \\
\hline 24 & Lintang Maulida Aulia & $\mathrm{P}$ & 70 & 60 & 80 \\
\hline 25 & Marcela Zita Vaneta & $\mathrm{P}$ & 70 & 80 & 90 \\
\hline 26 & Muchlis Arief & $\mathrm{L}$ & 60 & 70 & 80 \\
\hline 27 & Muhammad Irfan & $\mathrm{L}$ & 40 & 70 & 80 \\
\hline 28 & Nining Sertianingsih & $\mathrm{P}$ & 50 & 70 & 80 \\
\hline 29 & Noer Fadillah F.K. & $\mathrm{P}$ & 70 & 80 & 90 \\
\hline 30 & Nur'aisyah & $\mathrm{P}$ & 40 & 60 & 75 \\
\hline 31 & Piqi Saptarudi & $\mathrm{L}$ & 60 & 70 & 80 \\
\hline 32 & Putri Ameliya & $\mathrm{P}$ & 70 & 70 & 80 \\
\hline 33 & Putri Dewi & $\mathrm{P}$ & 50 & 60 & 75 \\
\hline 34 & Rahma Dita & $\mathrm{P}$ & 50 & 60 & 80 \\
\hline 35 & Rehan Malik & $\mathrm{L}$ & 60 & 80 & 90 \\
\hline
\end{tabular}




\begin{tabular}{cccc} 
Jumlah & 1580 & 2560 & 2680 \\
Rata-Rata & 54,77 & 67,39 & 80,48 \\
\hline
\end{tabular}

Tingkat pencapaian penguasaan materi Bahasa Indonesia tentang "Meresensi Buku Ilmu Pengetahuan" mengalami peningkatan dengan rata-rata 54,77 pada pra test, pada siklus 1 mencapai rata-rata 67,39, dan pada siklus 2 mencapai rata-rata 80,48.

Dari data hasil pembahasan secara kuantitatif terhadap hasil pretest dan post test siswa dalam belajar Bahasa Indonesia pada materi "Meresensi Buku Ilmu Pengetahuan" yaitu hasil awal menunjukkan skor rata-rata sebesar 54,77 , hasil pada siklus I naik menjadi skor rata-rata sebesar 67,39, dan hasil pada siklus II naik menjadi skor rata-rata sebesar 80,48. Dengan demikian, meningkatnya nilai dari hasil evaluasi belajar Bahasa Indonesia pada materi "Meresensi Buku Ilmu Pengetahuan" pada tiap siklusnya, berarti pemahaman siswa Kelas IXD SMPN 2 Jamblang pada materi tersebut menunjukkan adanya peningkatan yang cukup signifikan. Hal ini dapat dilihat melalui diagram grafik.

Hasil temuan secara kualitatif dalam penelitian tindakan kelas yang telah dilakukan pada siklus I dan siklus II, maka diperoleh sebagai berikut: aktivitas siswa dalam mengikuti kegiatan pembelajaran Bahasa Indonesia pada materi "Meresensi Buku Ilmu Pengetahuan", seperti Siswa yang bisa menjawab pertanyaan atau permasalahan meningkat, Siswa yang menyampaikan pendapat meningkat, Siswa yang memperhatikan secara aktif meningkat, siswa yang mengajukan pertanyaan atau mengungkapkan permasalahan cukup meningkat, siwa yang bekerja dan belajar secara aktif.

\section{Simpulan}

Dari Hasil penelitian dan pembahasan tentang penerapan Model Skrip Kooperatif dalam pembelajaran Bahasa Indonesia pada materi "Meresensi Buku Ilmu Pengetahuan" di kelas IXD SMPN 2 Jamblang pada siklus I dan II dapat disimpulkan bahwa terjadi peningkatan aktivitas belajar selama pembelajaran bahasa Indonesia. Hasil Belajar siswa baik secara individu maupun kelompok mengalami peningkatan pada tiap siklusnya. Dengan demikian penerapan Model Skrip Kooperatif dalam pembelajaran Bahasa Indonesia dapat Meningkatkan Pemahaman siswa pada materi "Meresensi Buku Ilmu Pengetahuan" di kelas IXD SMPN 2 Jamblang Kabupaten Cirebon.

\section{Daftar Pustaka}

Adi, F. M., Phang, F. A., \& Yusof, K. M. (2012). Student Perceptions Change in a Chemical Engineering Class using Cooperative Problem Based Learning (CPBL). Procedia - Social and Behavioral Sciences, 56, 627-635. https://doi.org/10.1016/j.sbspro.2012.09.697

Arikunto, S. (2006). Prosedur Penelitian Tindakan Kelas. Bumi Aksara.

Aryati, T. (2017). Meningkatkan Aktivitas Dan Hasil Belajar Bahasa Indonesia Pada Materi Cerpen Melalui Penerapan Model Pembelajaran Kooperatif Bermain Jawaban Di Kelas Xi Ips 5 Sman 10 Pekanbaru. PeKA: Jurnal Pendidikan Ekonomi Akuntansi, 5(2), 172-177. https://doi.org/10.1017/CBO9781107415324.004

Buchs, C., Gilles, I., Dutrévis, M., \& Butera, F. (2011). Pressure to cooperate: Is positive reward interdependence really needed in cooperative learning? British Journal of Educational Psychology. https://doi.org/10.1348/000709910X504799 
Johnson, D. W., \& Johnson, R. T. (1999). Making cooperative learning work. Theory into Practice. https://doi.org/10.1080/00405849909543834

Kasbolah, K. (2001). Penelitian Tindakan Kelas (PTK). Malang: Depdikbud.

Kusumawati, I. T., \& Sukidi, M. (2014). Penerapan Model Pembelajaran Kooperatif Tipe Stad Untuk Meningkatkan Hasil Belajar Teknik Pengelasan Pada Siswa Kelas X .... JPGSD, 2(2), 1-12. Retrieved from http://digilib.unimed.ac.id/id/eprint/21704

Laal, M., \& Ghodsi, S. M. (2012). Benefits of collaborative learning. Procedia - Social and Behavioral Sciences. https://doi.org/10.1016/j.sbspro.2011.12.091

Laal, M., Khattami-Kermanshahi, Z., \& Laal, M. (2014). Teaching and Education; Collaborative Style. Procedia - Social and Behavioral Sciences. https://doi.org/10.1016/j.sbspro.2014.01.890

Meilani, R., \& Sutarni, N. (2016). Penerapan Model Pembelajaran Cooperative Script Untuk Meningkatkan Hasil Belajar. Jurnal Pendidikan Manajemen Perkantoran, 1(1), 176. https://doi.org/10.17509/jpm.v1i1.3349

Oxford, R. L. (1997). Cooperative Learning, Collaborative Learning, and Interaction: Three Communicative Strands in the Language Classroom. The Modern Language Journal. https://doi.org/10.2307/328888

Salamiah. (2018). Penerapan Model Pembelajaran Kooperatif Tipe Script Untuk Meningkatkan Hasil Belajar Bahasa Indonesia Pada Materi Menyimak Cerita Siswa Kelas Vi Sd Negeri 020 Tembilahan Hilir. Jurnal PAJAR (Pendidikan Dan Pengajaran), 1(1), 1-10. https://doi.org/10.1017/CBO9781107415324.004

Sriarunrasmee, J., Suwannatthachote, P., \& Dachakupt, P. (2015). Virtual Field Trips with Inquiry learning and Critical Thinking Process: A Learning Model to Enhance Students' Science Learning Outcomes. Procedia - Social and Behavioral Sciences. https://doi.org/10.1016/j.sbspro.2015.07.226

Sudjana, N. (2012). Dasar-dasar proses mengajar. In Bandung: Sinar Baru Algensindo.

Wardani. (2007). Penelitian Tindakan Kelas. Jakarta: Universitas Terbuka.

Zain, S. B. D. dan A. (2006). Strategi Belajar Mengajar. Jakarta: PT Rineka Cipta. Syaiful Bahri Djamarah Dan Aswan Zain. https://doi.org/10.1016/j.bbapap.2013.06.007 